\title{
Frequency of dog erythrocyte antigen 1 blood group and risk of incompatible transfusion in dogs of different breeds and mongrels from the city of Salvador - BA, Brazil
}

\author{
Frequência do antígeno eritrocitário canino 1 e o risco de transfusão \\ incompatível em cães de diferentes raças e mestiços da cidade de \\ Salvador - BA, Brasil
}

\author{
Suzana Cláudia Spínola dos Santos ${ }^{1}$ (D); Mariane Melo dos Santos²; Wellington Francisco Rodrigues ${ }^{3}$; \\ Roberto Meyer²; Maria de Fátima Dias Costa ${ }^{4}$
}

\begin{abstract}
${ }^{1}$ Universidade Federal da Bahia, Instituto de Ciências da Saúde, Programa de Pós-graduação em Processos Interativos dos Órgãos e Sistemas, Salvador - BA, Brazil

${ }^{2}$ Universidade Federal da Bahia, Instituto de Ciências da Saúde, Laboratório de Imunologia e Biologia Molecular, Salvador - BA, Brazil

${ }^{3}$ Universidade Federal do Triângulo Mineiro, Programa de Pós-graduação em Ciências da Saúde/Biologia Celular, Uberaba - MG, Brazil

${ }^{4}$ Universidade Federal da Bahia, Instituto de Ciências da Saúde, Laboratório de Neuroquímica e Biologia Celular, Salvador - BA, Brazil
\end{abstract}

\begin{abstract}
The dog erythrocyte antigen 1 (DEA 1) is the most immunogenic blood group in dogs, and blood transfusions may trigger some undesirable effects in veterinary patients, which are directly associated with incompatible transfusions. The present study aimed to investigate the frequency of positive DEA 1 blood group in blood donor dogs from a blood bank in Salvador-BA, Brazil, and also to calculate the risk of managing incompatible blood in both first and second transfusion. A number of 203 dogs of different breeds, aged between 1 and 8 years, weighing $28 \mathrm{~kg}$, with no degree of kinship and of both sexes in Salvador-BA, Brazil were evaluated to investigate the blood type DEA 1 frequency, by means of chromatography and flow cytometry tests for blood typing. The risk of incompatible blood transfusion in either a first or a second transfusion was also calculated. The frequency of the DEA 1 group ranged in various breeds, but with a mean positivity of $62.07 \%(126 / 203)$. And the lowest risk of an DEA 1 negative animal receiving DEA 1 positive blood within the group of animals evaluated was $0.92 \%$ at a first transfusion; and the risk of the same animal receiving incompatible blood for the DEA group 1 in the second transfusion was $0.008 \%$. The highest risk of an DEA 1 negative animal receiving DEA 1 positive blood from these animals was $69.12 \%$; and the risk of receiving incompatible blood for DEA 1 was $47.77 \%$. In conclusion, the frequency of the DEA 1 group varied between the studied breeds. Also, the risk of incompatible blood transfusions, based on the frequency of DEA 1 group, varies according to donor and recipient breeds, but this can be overridden if blood typing tests are performed along with the cross-reaction test for compatibility. Keywords: DEA 1. Typification in dogs. Transfusion risk in dogs. Veterinary transfusion medicine.
\end{abstract}

\section{RESUMO}

O antígeno eritrocitário canino 1 (AEC 1) é o grupo sanguíneo mais imunogênico em cães e as transfusões sanguíneas podem desencadear alguns efeitos indesejáveis nos pacientes veterinários devido à transfusões incompatíveis. O presente trabalho investigou a frequência do grupo sanguíneo AEC 1 em cães doadores de sangue de um banco de sangue de Salvador-BA, Brasil, e calculou o risco da administração de sangue incompatível tanto em uma primeira quanto em uma segunda transfusão. Foram avaliados 203 cães de diversas raças, de ambos os sexos, com idade variando de um a oito anos, peso a partir de $28 \mathrm{~kg}$, sem nenhum grau de parentesco, originários de Salvador-BA, Brasil. A pesquisa da frequência do tipo sanguíneo AEC 1 foi realizada com o emprego de testes de imunocromatografia e citometria de fluxo para tipagem sanguínea. O risco de transfusão sanguínea incompatível foi calculado tanto em uma primeira como em uma segunda transfusão. A frequência do grupo AEC 1 variou entre as raças estudadas, encontrando-se uma positividade média de 62,07\% (126/203). O menor risco de um animal AEC 1 negativo receber sangue AEC 1 positivo dentro do grupo dos animais avaliados foi de $0,92 \%$ em uma primeira transfusão, e o risco de o mesmo animal receber sangue incompatível para o gruo AEC 1 na segunda transfusão foi de $0,008 \%$. O maior risco de um animal AEC 1 negativo receber sangue AEC 1 positivo foi de $69,12 \%$, e o risco de o mesmo animal receber sangue incompatível para o AEC 1 foi de $47,77 \%$. 
Concluindo, a frequência do grupo AEC 1 variou entre as raças estudadas. O risco de transfusões incompatíveis, baseado no grupo AEC 1, variou de acordo com as raças doadoras e receptoras, mas esse risco pode ser anulado caso venham a ser realizados os testes para tipagem sanguínea juntamente à prova de reação cruzada para compatibilidade.

Palavras-chave: AEC 1. Tipagem sanguínea canina. Risco transfusional canino. Medicina transfusional veterinária.

\section{Correspondence to:}

Suzana Cláudia Spínola dos Santos

Universidade Federal da Bahia, Instituto de Ciências da Saúde,

Programa de Pós-graduação em Processos Interativos dos

Órgãos e Sistemas

Av. Reitor Miguel Calmon, 1272, Canela

CEP: 40231-300, Salvador - BA, Brazil

e-mail: suzanaspinola@gmail.com

Received: February 17, 2019

Approved: June 27, 2019

How to cite: Santos SCS, Santos MM, Rodrigues WF, Meyer $\mathrm{R}$, Costa MFD. Frequency of dog erythrocyte antigen 1 blood group and risk of incompatible transfusion in dogs of different breeds and mongrels from the city of Salvador - BA, Brazil. Braz J Vet Res Anim Sci. 2019;56(3):e154865. https://doi.org/10.11606/issn.1678-4456.bjvras.2019.154865

\section{Introduction}

The DEA 1 blood group, like the other groups, is autosomal dominant, so there is a predominance in dogs with genetic proximity (the breed factor) or consanguinity (Giger, 2014; Hohenhaus, 2004; Iazbik et al., 2010). The strong antigenicity of DEA 1 means that donor blood typing is always recommended (Giger, 2014). A rigorous selection of donors minimizes the risk of transfusion reactions. This frequency could evaluate the risk of incompatible blood transfusion in both the first and second transfusions in some breeds and mongrels.

Currently in veterinary medicine, safe practice of blood transfusions is gaining more and more prominence, establishing pre-transfusion standards for donor animals to standardize pre-transfusion evaluation (Tocci \& Ewing, 2009).

It is known that for a safe blood transfusion it is important to use typified and compatible blood (Giger, 2014). The recognition of blood types in immunohematology in different canine populations of various breeds has been established for the maintenance of a data file of the donors (Esteves et al., 2011).

The present work investigated the blood type DEA 1 frequency, through blood chromatography tests and flow cytometry, with blood samples from donor dogs of different breeds with no degree of kinship in Salvador-BA, Brazil, and calculated the risk of transfusing incompatible blood in either a first or second transfusion.

\section{Materials and Methods}

Based on a statistical analysis of $95 \%$ confidence in sampling, in which a $90 \%$ success fraction was observed in the literature, the sample calculation took into account a success fraction around $85 \%$, using a 5\% error and a confidence interval of the tests, corresponding to $95 \%$. Following this calculation, the study would need to be performed with a minimum number of 196 dogs of various non-related breeds in Salvador-BA, Brazil.

A total of 203 blood donor dogs of different breeds with ages ranging from 1 to 8 years and weighing over $28 \mathrm{~kg}$ of both sexes, from a blood bank in Salvador-BA, Brazil, were tested. Among the breeds for blood donation were: 16 dogs of the Labrador Retriever breed; 31 dogs of the Golden Retriever breed; 12 dogs of the Afghan Hound breed; 14 dogs of the Belgian Shepherd Malinois breed; 14 dogs of the German Shepherd breed; 28 dogs of Bulldog breeds (Bulldog group) and 40 dogs of diverse defined breeds (Various Defined Breeds) (Chart 1); and 48 mongrels.

Through the results of the chromatography, a prevalence study of the canine blood type DEA 1 was performed with the donor dogs typified with no degree of kinship based on the birth records in our possession and by their guardians' information of various breeds confirmed based on the Fédération Cynologique Internationale (http://www.fci.be/en/). Chromatography was the technique chosen to calculate the prevalence because it is an already standardized technique, recognized and available worldwide, and the Alvedia ${ }^{\circledR}$ kit (Limonest-France) was used. The samplings were also tested through flow cytometry, according to Santos et al. (2018), confirming the results found. In order to perform the flow cytometry, the cytometer Becton Dickinson FACSCalibur ${ }^{\mathrm{TM}}$ interconnected to a PC Power Macintosh (Apple, Salvador, BA, Brazil, Laboratory of Immunology of the Federal University of Bahia) was used along with the instrument-specific software (BD CellQuest Pro ${ }^{\mathrm{TM}}$ software, Becton, Dickinson and Company).

We also calculated the risk of sensitization of dogs with blood that was not submitted to the compatibility test and typing in the first and in the second transfusion, according to the prevalence of DEA 1.

The formulas used to calculate the risk after the first transfusion and after the second transfusion according to 
the prevalence found of DEA 1 positive in this study are shown below, according to Spada et al. (2016).

First transfusion:

$\frac{(\% \text { negative DEA } 1 \times \% \text { positive DEA } 1)}{100}$

Second transfusion:

$\frac{(\% \text { negative DEA } 1 \times \% \text { positive DEA } 1) \times(\% \text { first transfusion sensibilization })}{10.000}$

For a descriptive, analytical study with qualitative variables, the frequencies of the DEA 1 group were compared between the breeds, and the existence of an association between the variables breed and blood group was verified by the Chi square test. The analyses were considered statistically significant at $\mathrm{p}<0.05$ (Arango, 2005). The analyses and the figure were performed using Prism 5 software version 5.01. The determination of the risk of incompatible blood use was performed with calculations based on the risk of a negative animal receiving blood from a positive dog both in the first and second transfusions, considering the breeds of larger and lower frequencies of the DEA 1 group.

\section{Results}

The sampling from this study revealed a frequency of $62.07 \%(126 / 203)$ of the DEA 1 blood group. The highest rate of DEA 1 negative results $(28 / 28 ; 100 \%)$ was found in the Bulldog group, while in the Belgian Shepherd dogs of Malinois (14/14; 100\%) and Afghan hound (12/12; 100\%), the highest rate of DEA 1 positive was found. Table 1 shows the frequencies in the groups studied and the Figure 1 infer a significant association of the qualitative variable addressed in this study (results DEA 1 antigen positive or negative), in relation to the dog breeds $(\mathrm{p}<0.0001)$.
The lowest risk of a DEA 1 negative animal receiving DEA 1 positive blood within the group of animals evaluated was $0.92 \%$ at a first transfusion, and the risk of the same animal receiving incompatible DEA 1 blood at the second transfusion was $0.008 \%$. The highest risk of a DEA 1 negative animal receiving DEA 1 positive blood was $69.12 \%$ and the risk of receiving non-DEA 1 blood was $47.77 \%$. Possible transfusions were analyzed that could sensitize the dogs

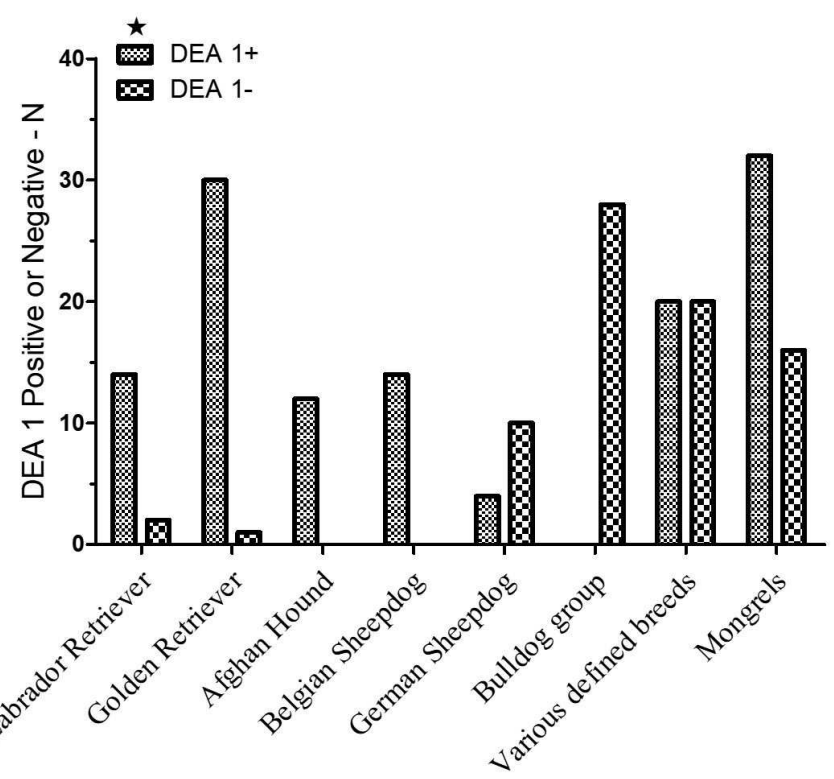

Figure 1 -Associative inference between qualitative test for dog erythrocyte antigen 1 (DEA 1) and dog breeds. After checking the absolute frequency of positive or negative results for DEA 1 by means of immunochromatography, the association was assessed using the chi-square test. The "X" axis describes the breeds of dogs evaluated in this study. In the "Y" axis, the absolute values of the positivity or negativity results for the DEA 1 are expressed. $* \mathrm{P}<0.0001$.

Chart 1 - Breeds and number of included animals in the groups respectively: Bulldogs group and Various Defined Breeds group

Bulldog group:

English Bulldog (10), Old English Bulldog (6), American Bulldog (9),

Bulldog Campeiro (3)

Various Defined Breeds group:

Akita (4), American Pitt Bull Terrier (6), American Staffordshire Terrier (7), Boxer (3), Bull Terrier (2), Chow (2), Doberman (3), Brazilian

Mastiff (2), Siberian Husky (2), Kuvasz (1), Rottweiler (5), Samoyed (2), Weimaraner (1)

Table 1 - Total number and frequency (\%) of the DEA 1 blood group among the different breeds studied. Salvador, 2017

\begin{tabular}{|c|c|c|c|c|c|}
\hline Breeds & No. of animals & DEA 1+ & $\%$ & DEA 1- & $\%$ \\
\hline Labrador Retriever & 16 & 14 & $87.5 \%$ & 2 & $12.50 \%$ \\
\hline Golden Retriever & 31 & 30 & $96.77 \%$ & 1 & $3.23 \%$ \\
\hline Afghan Hound & 12 & 12 & $100 \%$ & 0 & $0 \%$ \\
\hline Belgian Shepherd Malinois & 14 & 14 & $100 \%$ & 0 & $0 \%$ \\
\hline German Shepherd & 14 & 4 & $28.57 \%$ & 10 & $71.43 \%$ \\
\hline Bulldog group & 28 & 0 & $0 \%$ & 28 & $100 \%$ \\
\hline Diverse Defined Breeds & 40 & 20 & $50 \%$ & 20 & $50 \%$ \\
\hline Mongrel & 48 & 32 & $66.67 \%$ & 16 & $33.33 \%$ \\
\hline Total & 203 & 126 & $62.07 \%$ & 77 & $37.93 \%$ \\
\hline
\end{tabular}


that presented frequency to the DEA 1 negative group from $33.33 \%$ to $71.43 \%$ with higher frequency donors from the DEA 1 positive group (Table 2). The risk was analyzed among animals of the same classification by breed groups (Tables 3 and 4) and the risk of the most frequent animals with presence of the DEA group 1 to receive blood from the DEA 1 positive group by animals that presented the lowest frequencies of the DEA 1 positive group (Table 5).

\section{Discussion}

The sampling in this study revealed a frequency (62.07\%) like that found by Souza et al. (2014) in São Paulo, with a frequency of $71 \%$ through a sample of $300 \mathrm{dogs}$, also composed of different breeds. There were groups that had the highest rate of DEA 1 negative (Bulldogs), while other breeds showed the highest rate of DEA 1 positive (Belgian Shepherd Malinois and Afghan Hound). These results are related to the genetic factor of dominance, as demonstrated by Giger et al. (2005). They obtained 100\% positivity in their studies with the Saint Bernard breed and most Golden Retriever dogs, which were also positive DEA 1 . This is due to factors such as the geographic area studied, where usually individuals from distant areas are not brought in for breeding and also genetic factors of each breed. Moreover, this is due to the predominant autosomal dominant feature in dogs of the same breed or consanguinity (Acierno et al., 2014; Hohenhaus, 2004; Iazbik et al., 2010; Mesa-Sanchez et al., 2014).

The high incidence of a blood group may also be related to local breeds, as this influence was evident in studies conducted in Croatia with the Croatian Sheepdog breed with incidence of DEA 1.1 blood type with $90 \%$ positivity (Zubcic et al., 2008). It was also performed in Croatia, with the Dalmatian breed, showing 95\% positivity (Gracner et al., 2011). Riond et al. (2011) found $100 \%$ positive DEA 1.1 in the Rottweiler and Bernese Mountain Dog, and 75\% in Labrador dogs and $77 \%$ in Golden Retriever dogs in Switzerland. In our study, more than the results presented

Table 2 - Risk (\%) of a negative receptor (-) receiving positive blood (+) for the DEA 1 group in the 1 st and 2 nd transfusions according to the animals that had a rate between $33.33 \%$ and $71.43 \%$ of DEA 1 - among them: German Shepherds (G.S.), Diverse Defined Breeds (D.D.B.) and Mongrels (M.), with donor of the group of the breeds of a higher rate of DEA 1+: Labrador (L.) and Golden Retriever (G.R.) Salvador, 2017

\begin{tabular}{|c|c|c|c|c|c|c|}
\hline & \multicolumn{2}{|c|}{ Receptor G.S. - } & \multicolumn{2}{|c|}{ Receptor D.D.B. - } & \multicolumn{2}{|c|}{ Receptor M. - } \\
\hline & 1st & $2^{\text {nd }}$ & 1st & 2nd & 1st & 2nd \\
\hline Donor L. + & $62.5 \%$ & $39.06 \%$ & $43.75 \%$ & $19.14 \%$ & $29.16 \%$ & $8.5 \%$ \\
\hline Donor G.R. + & $69.12 \%$ & $47.77 \%$ & $48.38 \%$ & $23.4 \%$ & $32.25 \%$ & $10.4 \%$ \\
\hline
\end{tabular}

Table 3 - Risk (\%) of a negative receptor (-) receiving positive blood $(+)$ for the DEA 1 group in the 1 st and 2 nd transfusion according to the animals that presented the lowest DEA 1 - among all studied: Labradors (L.) and Golden Retrievers (GR) Salvador, 2017

\begin{tabular}{|c|c|c|c|c|}
\hline & \multicolumn{2}{|c|}{ Receptor L. - } & \multicolumn{2}{|c|}{ Receptor G.R. - } \\
\hline & $1 \mathrm{st}$ & 2nd & $1 \mathrm{st}$ & 2nd \\
\hline Donor L. + & $10.93 \%$ & $1.19 \%$ & $2.82 \%$ & $0.07 \%$ \\
\hline Donor G.R. + & $12.09 \%$ & $1.46 \%$ & $3.12 \%$ & $0.97 \%$ \\
\hline
\end{tabular}

Table 4 - Risk (\%) of a negative (-) recipient receiving positive $(+)$ blood for the DEA 1 group in the 1 st and 2 nd transfusion according to the animals that presented a DEA 1 rate between $33.33 \%$ and $71,43 \%$ among all studied: German Shepherds (G.S.), Diverse Defined Breeds (D.D.B.) and Mongrels (M.), among themselves. Salvador, 2017

\begin{tabular}{|c|c|c|c|c|c|c|}
\hline & \multicolumn{2}{|c|}{ Receptor G.S. - } & \multicolumn{2}{|c|}{ Receptor D.D.B. - } & \multicolumn{2}{|c|}{ Receptor M.B. - } \\
\hline & $1 \mathrm{st}$ & $2^{\text {nd }}$ & $1 \mathrm{st}$ & 2nd & 1st & 2nd \\
\hline Donor G.S. + & $20.4 \%$ & $4.16 \%$ & $14.28 \%$ & $2.03 \%$ & $9.52 \%$ & $0.9 \%$ \\
\hline Donor D.D.B. + & $35.71 \%$ & $12.75 \%$ & $25 \%$ & $6.25 \%$ & $16.66 \%$ & $2.77 \%$ \\
\hline Donor M.B. + & $47.62 \%$ & $22.67 \%$ & $16.66 \%$ & $2.77 \%$ & $22.22 \%$ & $4.93 \%$ \\
\hline
\end{tabular}

Table 5 - Risk (\%) of a negative receptor (-) receiving positive blood (+) for the DEA 1 group in the 1 st and 2 nd transfusion according to the animals that presented the lowest DEA 1 - among all studied: Labradors (L.) and Golden Retrievers (GR), with animals with DEA group $1+$ between $28.57 \%$ and $66.67 \%$. Salvador, 2017

\begin{tabular}{|c|c|c|c|c|}
\hline & \multicolumn{2}{|c|}{ Receptor L. - } & \multicolumn{2}{|c|}{ Receptor G.R. - } \\
\hline & 1st & $2^{\text {nd }}$ & $1 \mathrm{st}$ & 2nd \\
\hline Donor G.S. + & $3.57 \%$ & $0.12 \%$ & $0.92 \%$ & $0.008 \%$ \\
\hline Donor D.D.B.+ & $6.25 \%$ & $0.39 \%$ & $1.61 \%$ & $0.02 \%$ \\
\hline Donor M.B. + & $8.33 \%$ & $0.69 \%$ & $2.15 \%$ & $0.46 \%$ \\
\hline
\end{tabular}


by Riond et al. (2011), the Labrador and Golden Retriever breeds presented a highest incidence of DEA 1 (87.5\% and $96.77 \%$, respectively).

The dogs of the German Shepherd breed had the lowest incidence of the DEA 1 group, shortly after the Bulldog group like that found by Riond et al. (2011) with DEA 1.1, which was $25 \%$. Souza et al. (2014), in São Paulo, found $32 \%$ positive results in German Shepherd dogs, while for DEA 1.1. they found 1\%. Novais et al. (1999), also in São Paulo, found the highest DEA 1.1 frequency in this breed, which was 36.84. Still, at a national level, Esteves et al. (2011), in Rio Grande do Sul, found a frequency of $10 \%$ for the DEA 1.1 type. In Poland, Milczak et al. (2016) found a DEA 1.1 frequency of $15 \%$. The null frequency $(0 \%)$ of the DEA 1.1 type in German Shepherd dogs was observed in Portugal by Ferreira et al. (2011); and the second lowest frequency found was of $8 \%$, by Carli et al. (2017), testing the DEA 1 group with the highest sampling of dogs of this breed ( 65 animals) among studies already done.

Here, the group Diverse Defined Breeds and Mongrels presented a frequency approximating the mean result of total sampling frequency. Compared to other localities, the incidences of positive DEA 1 in different breed groups, with close percentages, were found by Carli et al. (2017) in Italy with 62\%; Esteves et al. (2011) in Rio Grande do Sul, Brazil, with 61\%; Spada et al. (2015) in Spain with 54.6\%; and Riond et al. (2011) with 53\%. The percentage found near the group described here as Mongrels was $49 \%$ in the Mongrels researched by Riond et al. (2011).

Dog breeds generally exhibit reduced genetic diversity due to intense inbreeding to preserve and select breed characteristics. The high frequency of the DEA 1 group in some breeds of this study can thus be explained. Knowing the frequencies between the blood donor dog breed generates greater efficiency in the selection of appropriate donor dogs, suggesting a possible identification of the DEA 1 negative donors, similar to what was found in the Bulldog and German Shepherd groups.

A blood transfusion of an animal from the DEA 1 positive group to a DEA 1 negative group will invariably develop a strong production of alloantibodies. After a first transfusion, antibodies can develop after up to 4 days, which can lead to a late transfusion reaction. More intensely, this receptor may develop an acute hemolytic reaction after a second transfusion with DEA 1 positive blood (Giger et al., 2005; Giger, 2014).

The risk of incompatible transfusion studied in a first transfusion and in the second transfusion of the same animal receiving incompatible blood, which was presented here, showed results resembling those found by Souza et al. (2014) in São Paulo, ranging from $0.6 \%$ to $66.6 \%$ in a first incompatible transfusion, and from $0.21 \%$ to $65.3 \%$ of the same animal in an incompatible second transfusion.

Previous research has revealed a transfusion risk in the first and second transfusion that differs from the findings in this study. Ekiz et al. (2011) found a risk of sensitization in the first transfusion from $20.5 \%$ to $25 \%$ within the same breed, and in a second transfusion a risk of $12.5 \%$ to $14.8 \%$. Ferreira et al. (2011) found a risk of sensitization in the first transfusion in several breeds of $24.5 \%$. Dhliwayo et al. (2016), studying the DEA 1.1 frequency in mongrels, found $78 \%$ positivity and a risk of incompatibility between them in the first transfusion of $17.2 \%$, and in a second incompatible transfusion a risk of $2.95 \%$. Mesa-Sanchez et al. (2014) studying the prevalence of the DEA 1.1 type in Greyhound dogs in Spain found a potential risk of sensitization within the same breed of $22.9 \%$ after the first blood transfusion, when not typed or cross-reacted.

The variations found in this study were because there were breeds in which the DEA 1 group prevailed, and others showed a lower frequency. The lowest rates of risk of incompatibility occurred in the prospecting of transfusions among individuals of the same breed, which were those of the Golden Retriever and Labrador. The receptors of these breeds studied here were the least susceptible to the risk of incompatible transfusions, both in the first and second transfusions, due to the fact that they were the representatives of the highest frequency of the DEA 1 group out of the breeds that presented $100 \%$ positivity to the DEA 1 group. If they were recipients of dogs whose frequency of the DEA 1 group varied from $28.57 \%$ to 66.67\% (German Shepherd, Diverse Defined Breeds and Mongrels), the transfusion risks in a first transfusion and in a second transfusion could be even less.

For the Afghan Hound and Belgian Shepherd Malinois group of dogs, there were no prospects for transfusion risk because they were $100 \%$ positive, which would generate a sensitization already known in DEA 1 negative subjects and no risk in transfusions among them by the DEA 1 group. The same conclusion was drawn for the $100 \%$ negative animals, where there would be no transfusion risk for individuals of positive or negative DEA 1 groups.

According to Giger (2014), the typing for the DEA 1 group and other blood types does not eliminate the need to be cross-reactive before the first transfusion because it can identify incompatibilities against some unknown blood types today. Furthermore, the rarest reaction transfusions are against the DEA 4 and Dal blood types, and there may 
be another clinically important type to be discovered in the future. The results of the articles cited here together with the findings of the present study reinforce the need to select canine blood donors for the positive and negative DEA 1 group as well as the need for the cross-reaction test prior to any blood transfusion. This should be a clinical and laboratory practice for transfusion therapy to be safe for the recipient, especially for dogs that will receive more than one blood transfusion.

\section{Conclusion}

The frequency of the DEA 1 group varied between the studied breeds, due to the autosomal dominant factor of this group in each.

The risk of incompatible blood transfusions, based on the frequency of DEA 1 group, varies according to donor and recipient breeds, but this can be overridden if blood typing tests are performed along with the cross-reaction test for compatibility.

\section{References}

Acierno MM, Raj K, Giger U. DEA 1 expression on dog erythrocytes analysed by immunochromatographic and flow cytometric techniques. J Vet Intern Med. 2014;28(2):5928. http://dx.doi.org/10.1111/jvim.12321. PMid:24611973.

Arango HG. Bioestatistica teórica e computacional. 2a ed. Rio de Janeiro: Guanabara Koogan; 2005. 423 p.

Carli E, Carminato A, Ravagnan S, Capello K, Antognoni MT, Miglio A, Furlanello T, Proverbio D, Spada E, Stefani A, Mutinelli F, Vascellari M. Frequency of DEA 1 antigen in 1037 mongrel and purebred dogs in Italy. BMC Vet Res. 2017;13:364. http://dx.doi.org/10.1186/s12917-017-1286-y. PMid:29187176.

Dhliwayo S, Makonese TA, Whittall B, Chikerema SM, Pfukenyi DM, Tivapasi MT. A study on the prevalence of dog erythrocyte antigen 1.1 and detection of canine Babesia by polymerase chain reaction from apparently healthy dogs in a selected rural community in Zimbabwe. J S Afr Vet Assoc. 2016;87(1):1-5. http://dx.doi.org/10.4102/jsava. v87i1.1409. PMid:27796108.

Ekiz EE, Arslan M, Ozcan M, Gultekin GI, Gulay OY, Kirmizibayrak T, Giger U. Frequency of dog erythrocyte antigen 1.1 in 4 breeds native to different areas in Turkey. Vet Clin Pathol. 2011;40(4):518-23. http://dx.doi.org/10.1111/ j.1939-165X.2011.00370.x. PMid:22136478.

\section{Conflict of Interest}

The authors declared no potential conflicts of interest with respect to the research, authorship, and publication of this article.

\section{Ethics Statement}

The present study was conducted in accordance with Law No. 11,794, on October 8, 2008, Decree No. 6,899, on July 15,2009 , and the norms issued by the National Council for the Control of Animal Experimentation (CONCEA), and was approved by the Ethics Committee on the Use of Animals of the Institute of Health Sciences (CEUA-ICS), in a meeting on August 12, 2016.

\section{Acknowledgements}

This work was supported by the Veterinary Clinic Diagnose Animal, in Bahia, the Immunology Laboratory of the Federal University of Bahia, and the Neurochemical Laboratory of the Federal University of Bahia, in Brazil.

Esteves VS, Lacerda LA, Lasta CS, Pedralli V, González FHD. Frequencies of DEA blood types in a purebreed canine blood donor population in Porto Alegre, R.S., Brazil. Pesq Vet Bras. 2011;31(2):178-81. http://dx.doi.org/10.1590/ S0100-736X2011000200015.

Ferreira RRF, Gopegui RR, Matos AJF. Frequency of dog erythrocyte antigen 1.1 expression in dogs from Portugal. Vet Clin Pathol. 2011;40(2):198-201. http://dx.doi.org/10.1111/j.1939-165X.2011.00311.x. PMid:21554361.

Giger U. Blood typing and crossmatching to ensure blood compatibility. In: Bonagura JD, Twedt DC, editors. Kirk's current veterinary therapy XV. Philadelphia: Saunders; 2014. p. 143-8.

Giger U, Stieger K, Palos H. Comparison of various canine blood-typing methods. Am J Vet Res. 2005;66(8):138692. http://dx.doi.org/10.2460/ajvr.2005.66.1386. PMid:16173482.

Gracner D, Bedrica L, Potocnjak D, Sakar D, Samardzija M, Capak H, Gracner GG. Blood groups and haematology indicators in Croatian indigenous breeds of dog. II Dalmatian dog. Vet Arh [Internet]. 2011 [cited 2017 Jan 20];81(1):111-7. Available from: http://www.vef.unizg.hr/ vetarhiv/papers/2011-81-1-11.pdf 
Hohenhaus AE. Importance of blood groups and blood group antibodies in companion animals. Transfus Med Rev. 2004;18(2):117-26. http://dx.doi.org/10.1016/j. tmrv.2003.12.003. PMid:15067591.

Iazbik MC, O'Donnell M, Marin L, Zaldivar S, Hudson D, Couto CG. Prevalence of dog erythrocyte antigens in retired racing greyhounds. Vet Clin Pathol. 2010;39(4):4335. http://dx.doi.org/10.1111/j.1939-165X.2010.00261.x. PMid:21198732.

Mesa-Sanchez I, Ruiz de Gopegui-Fernández R, GranadosMachuca MM, Galan-Rodriguez A. Prevalence of dog erythrocyte antigen 1.1 in galgos (Spanish greyhounds). Vet Rec. 2014;174:351. http://dx.doi.org/10.1136/vr.102087. PMid:24578316.

Milczak A, Abramowicz B, Madany J, Winiarczyk D, Wrzesniewska K, Bochynska D, Sahinduran S. Frequency of DEA 1.1 antigen in german shepherds. Scientific Messenger of Lviv National University of Veterinary Medicine and Biotechnologies. 2016;18(3):221-4. http:// dx.doi.org/10.15421/nvlvet7151.

Novais AA, Santana AE, Vincentin LA. Prevalência do grupo sanguíneo DEA 1 (subgrupos 1.1 e 1.2) em cães (canis familiaris, Linaeus, 1758) criados no Brasil. Braz J Vet Res Anim Sci.. 1999;36(1):23-7. http://dx.doi.org/10.1590/ S1413-95961999000100004.

Riond B, Schuler E, Rogg E, Hofmann-Lehmann R, Lutz H. Prevalence of dog erythrocyte antigen 1.1 in dogs in Switzerland evaluated with the gel columm technique. Schweiz Arch Tierheilkd. 2011;153(8):369-74. http://dx.doi. org/10.1024/0036-7281/a000223. PMid:21780065.

Santos SCS, Moroz LR, Santos MM, Santos AS, Trindade SC, Meyer R, Costa MFD. Detection of canine anti-DEA 1 antibodies using flow cytometry in dogs following DEA 1-positive blood transfusion. Braz J Vet Res Anim Sci.
2018;55(1):1-7. http://dx.doi.org/10.11606/issn.1678-4456. bjvras.2018.122274.

Souza SL, Stopiglia AJ, Gomes SGR, Ulata SK, Moroz LR, Fantoni DT. Estudo da frequência dos antígenos eritrocitários caninos $1,1.1$ e 7 e risco de transfusão incompatível em cães de diferentes raças e mestiços da região metropolitana da cidade de São Paulo-SP, Brasil. Braz J Vet Res Anim Sci. 2014;51(4):316-23. http://dx.doi.org/10.11606/issn.16784456.v51i4p316-323.

Spada E, Proverbio D, Flórez LMV, Chamizo MRP, Perego R, De Giorgi GB, Baggiani L. Prevalence of dog erythrocyte antigens 1, 4 and 7 in galgos (Spanish Greyhounds). J Vet Diagn Invest. 2015;27(4):558-61. http://dx.doi. org/10.1177/1040638715592025. PMid:26179093.

Spada E, Proverbio D, Flórez LMV, Serna BSG, Chamizo MRP, Baggiani L, Perego R. Prevalence of dog erythrocyte antigens 1, 4 and 7 in Podenco Ibicenco (Ibizan Hounds) from Ibiza Island. Vet Med Int. 2016;2016:1048257. http:// dx.doi.org/10.1155/2016/1048257. PMid:27034890.

Tocci LJ, Ewing PJ. Increasing patient safety in veterinary transfusion medicine: an overview of pre transfusion testing. J Vet Emerg Crit Care. 2009;19(1):66-73. http://dx.doi. org/10.1111/j.1476-4431.2009.00387.x. PMid:19691586.

Zubcic D, Bedrica L, Gracner D, Harapin I, Fury M, Jeremic J. Blood groups, haematology and clinicolchemical indicators in indigenous breeds of dog. I. Croatian sheepdog. Vet Arh [Internet]. 2008 [cited 2015 Feb 18];78(2):141-7. Available from: http://www.vef.unizg.hr/vetarhiv/papers/2011-81-1-11.pdf

\section{Financial Support: None.}

Authors Contributions: Suzana Cláudia Spínola dos Santos, Mariane Melo dos Santos, Wellington Francisco Rodrigues, Roberto Meyer and Maria de Fátima Dias Costa contributed equally to this study. 